ISSN: $1130-3743$ - e-ISSN: 2386-5660

DOI: http://dx.doi.org/10.14201/teoredu2016282113138

\title{
FRIEDRICH NIETZSCHE: SOBRE LA EDUCACIÓN. UNA CONSIDERACIÓN INTEMPESTIVA
}

\author{
Friedrich Nietzsche: On Education. \\ An Unfashionable Observation
}

\section{Friedrich Nietzsche: sur l'éducation. Une considération inactuelle}

\author{
Fernando BÁRCENA ORBE \\ Universidad Complutense de Madrid. Facultad de Educación. \\ Departamento de Teoría e Historia de la Educación. \\ C/ Rector Royo Villanova, 1. Ciudad Universitaria. 28040 Madrid. \\ fernando@edu.ucm.es
}

Fecha de recepción: enero de 2016

Fecha de aceptación: marzo de 2016

\section{RESUMEN}

Se propone en este artículo una consideración intempestiva sobre la educación, desde un punto de vista nietzscheano. El principal propósito es pensar cierto desahucio contemporáneo de la experiencia de la educación entre las generaciones. Cuando sólo se enseña y transmite lo que tiene demanda social, la erosión de la educación como experiencia impredecible de formación (Bildung) resulta inevitable. Con el auge de la llamada "sociedad del aprendizaje», la insistencia en la función democrática de la educación escolar se ha visto acompañada por un cúmulo de demandas pedagógicas, provenientes de la sociedad y el mercado, cuyo efecto más inmediato es una sensación de asfixia sobre la experiencia educativa del aprender. Como se va a sostener en este texto, la educación tiene que ver no con lo posible, sino con lo imposible; no con las continuidades, sino con las interrupciones; no con la obsesión por la acción, sino con la pasividad y la demora. 
Palabras clave: Filosofía de la educación; Nietzsche y la educación; aprendizaje; generaciones; mundo común.

\section{SUMMARY}

It is proposed in this paper an educational' unfashionable observation, from an nietzschean point of view. The main purpose thinking about certain contemporary dispossession of the educational experiencie between generations. When the only thing to transmit is that which is soccialy demanded, the erosion of education as an unpredictable experience of Bildung turns out unavoidable. With the rise of the so called "Learning Society", the insistence on the democratic function of schoolastic education has been accompanied by a set of pedagogical demands, coming from society and the market, whose most immediate effect is a feeling of a suffocation on educational experience of apprenticeship. As is to be held in this text, education has to do, not with possibilities, but with the impossibilities, not with the continuities, but with interruptions, not only with action, but with passivity and delay.

Key words: Philosophy of Education; Nietzsche and education; Learning; Generations; Common World.

\section{SOMMAIRE}

Il est proposé dans cet article une considération inactuelle, au sens de Nietzsche, sur l'éducation. Le but principal est de penser la dépossession contemporaine de l'expérience de l'éducation entre les générations. Lorsque seulement enseigne et transmettre ce qui provient de la demande sociale, l'érosion de l'éducation comme formation (Bildung) et expérience imprévisible est inévitable. Avec la montée de la soi-disant "Société d'apprentissage», l'insistance sur la fonction démocratique de l'enseignement scolaire a été accompagnée par une foule de besoins éducatifs dérivés de la société et le marché, dont l'effet le plus immédiat est une sensation d'étouffement sur l'expérience éducative de l'apprentissage. Comme on doit se tenir dans ce texte, l'éducation doit faire, pas possible, mais avec l'impossible, pas avec les continuités, mais avec des interruptions, pas avec l'obsession de l'action, mais avec la passivité et le retard.

Mots clés: Philosophie de l'éducation; Nietzsche et l'éducation; apprentissage; générations; monde commun.

\section{INTRODUCCIÓN}

Nadie puede construirte el puente sobre el que precisamente tú tienes que caminar sobre el río de la vida, nadie lo puede hacer excepto tú, y sólo tú. En efecto, hay innumerables senderos y puentes y semidioses que quieren llevarte por el río; pero sólo a condición de que te vendas a ellos.

Nietzsche, Schopenhauer como educador (2011a, 751) 
Se ha dicho que "lo contemporáneo es lo intempestivo». Esta afirmación se puede leer en un curso dictado por Roland Barthes en el Collège de France en el año 1976 (Barthes, 2003, 48). La expresión alude a las «consideraciones intempestivas" -también llamadas «inactuales»- de Friedrich Nietzsche. En Sobre la utilidad y el perjuicio de la historia para la vida -la segunda de ellas, de 1874-, Nietzsche escribe que «esta meditación es también intempestiva porque yo trato de entender como un daño, como una enfermedad y un defecto de nuestra época algo de lo que ésta está orgullosa con razón, su formación histórica» (Nietzsche, 2011a, 696)ํ․ En la primera de ellas -David Strauss, el confesor y el escritor (1873)- Nietzsche descubre en el teólogo y filósofo alemán un prototipo de erudito al que alaba por su crítica al cristianismo, pero a quien reprocha también por poner otra religión de recambio. Y es que para el joven Nietzsche «la cultura es ante todo la unidad del estilo artístico de todas las manifestaciones de la vida de un pueblo. Sin embargo, ni el mucho saber ni la mucha erudición son un medio necesario para la cultura, o un signo de ella, y en caso contrario se entienden muy bien con lo contrario de la cultura, la barbarie, es decir: la falta de estilo o la confusión caótica de todos los estilos" (Nietzsche, 2011a, 643-644). Nietzsche insistía en que, en el verdadero sentido de la palabra, la cultura es la obra de individuos "incómodos", ya que su objetivo es la grandeza, no la felicidad o el bienestar, ni siquiera el progreso material. En la aludida segunda intempestiva, Nietzsche reconoce que un ser humano necesita el recurso de la memoria, pero al mismo tiempo declara con firmeza que para poder llegar a vivir hay que saber olvidar y recordar únicamente lo primordial (que nuestro origen es animal); o, dicho de otro modo, que hay que olvidar lo esencial: el peso anquilosado del pasado que no refuerza la vida. Por eso, Nietzsche cuestionará en qué medida la educación moderna (la de su tiempo) está enteramente supeditada a la ilusión de que el saber es capaz de proporcionar un acceso a la totalidad del mundo, una actitud que termina por transformar las disciplinas históricas, y a la historia misma, en una ciencia con pretensiones de objetividad, pero incapaz de problematizar ni atender el presente, como ha señalado Pavel Kouba (2009, 33).

El filósofo italiano Giorgio Agamben, al preguntarse: ¿Qué significa ser contemporáneo?, sugiere que lo que hace el filósofo alemán es emplazar su pretensión de "contemporaneidad" mediante el establecimiento de una distancia (y de una extrañeza) con respecto a su época, con la que no termina de coincidir. Ese gesto no tiene que ver con una actitud de nostalgia, como tampoco se trata de una impostura. El gesto apunta, más bien, a una «relación con el tiempo que se adhiere a éste a través de un desfase y un anacronismo" (Agamben, 2001, 18). Quiero aprovecharme aquí del gesto "anacrónico» nietzscheano (me adelanto a decir que este texto no es un trabajo sistemático sobre una posible filosofía de la educación

1. A lo largo del artículo citaré las ediciones en castellano de las ediciones de Nietzsche que me parecen más solventes. La edición alemana de las obras completas en 15 volúmenes se puede encontrar en NiETZSCHE (2008). 
de Nietzsche) para intentar recalcar mi propia distancia (personal) con respecto a determinados aspectos del momento presente de la educación -de los que también parece sentirse orgullosa nuestra época-, ingredientes que podrían ser susceptibles de la misma crítica que la que Nietzsche estableció con respecto a la educación de la Alemania de su tiempo.

Deseo poner el acento en lo que considero el desahucio contemporáneo de la idea de la "educación", entendida esta palabra en el sentido de una experiencia de "formación". Formación como acompañamiento del otro y encuentro con el mundo; formación como influencia educativa en el éthos del individuo en el seno de un encuentro entre generaciones (una cierta Paideia); y formación de un sentido artístico capaz de construir una mirada estética sobre el mundo y la realidad (como una cierta Bildung) ${ }^{2}$. Es cierto que estas imágenes han perdido toda su vigencia en los discursos pedagógicos actuales; pero evocarlas aquí -esta es la hipótesis- quizá nos permita repensar la educación como una ayuda destinada para que el individuo sea capaz de un mejor encuentro consigo mismo, empujándole a la búsqueda de todo lo grande que alberga una cultura arraigada en y productora -no negadorade vitalidad.

Al final de la segunda intempestiva antes mencionada, Nietzsche vuelve su mirada hacia la juventud, y se pregunta dónde encontrar la energía necesaria para renovar la acción, prometerse un porvenir y hacer nacer una genuina cultura: «Confío en la potencia inspiradora que a falta del genio lleva el timón de mi nave, confío en que la juventud me haya guiado bien al obligarme ahora a protestar contra la educación bistórica de la juventud del ser bumano moderno y a sostener la protesta de que el ser humano debe aprender, ante todo, a vivir y sólo ha de usar la historia al servicio de la vida aprendida" (Nietzsche, 2011a, 743). Quien quiera quebrar el tipo de educación -erudita y sin vida- que Nietzsche juzga tan severamente, debe alzar la palabra de la juventud y alumbrar -señala- el camino de su rebeldía; y hacer de ella «una conciencia que hable en voz alta». Nietzsche, por tanto, no ignora que si de lo que se trata es de afirmar y defender la vida, para que dé sus frutos, lo que hay que hacer es incidir en las nuevas y más jóvenes generaciones. Ahí está todo el meollo de la cuestión pedagógica, podríamos decir.

Por eso voy a insistir en la importancia de esta idea: la educación es, fundamentalmente, un encuentro entre generaciones en la filiación del tiempo: un encuentro entre vitalidades distintas que compromete actos de transmisión entre temporalidades enfrentadas (tiempo adulto y tiempo joven), donde se dan y prometen mutuamente

2. En efecto, la Paideia de la época helenística operaba sobre el éthos del individuo con el objeto de ayudarle a "armonizar" sus acciones con el orden del mundo. En este sentido, perseguía "curar" al alma de sus inquietudes y fragilidades, y estaba estrechamente conectada con el "cuidado de sí" (epimeleia heautou), en principio una tarea destinada a los ciudadanos libres y privilegiados, pero poco a poco cada vez más extendida como una exigencia para todos los ciudadanos. La palabra Bildung (formación), por su parte, parece designar de un modo intuitivo la esencia de la educación en el sentido griego del término, al incluir tanto la configuración artística y plástica como la imagen o idea de tipo normativo que se cierne sobre la intimidad del artista. 
cosas. La experiencia de este encuentro permite atisbar, más que posibilidades de transmisión de saberes técnicamente viables o destrezas, imposibilidades, y más que continuidades, interrupciones, quiebras, en suma, acontecimientos. Podría, desde luego, decirse que la tarea de los padres, como la de todo educador, es una labor hasta cierto punto imposible. Unos y otros -padres y educadores profesionales-, están llamados a educar "por su cuenta", a partir de sus propias insuficiencias, siempre expuestos al riesgo del error y del fracaso. Los mejores entre ellos son no los que se presentan a sí mismos como modelos moralmente ejemplares, ni como eruditos ni conocedores expertos del saber pedagógico, sino los que tienen conciencia de la naturaleza a la vez arriesgada e inevitable de un oficio que les desborda y que tiene mucho que ver con una erótica y una tekhné (en su sentido más artesanal) que requieren poder concederse tiempo y ejercitarse en el oficio: repetición, espera, demora, atención. Un oficio que precisa, pues, de un «tiempo libre» en vez de esclavo. Un tiempo que no mide el reloj de agua de Clepsidra.

Me interesa, por consiguiente, explorar otras maneras de pensar la educación y la experiencia íntima que configura el vínculo entre las generaciones que se encuentran, se rozan, se impulsan y educan. Y me importa señalar hasta qué punto eso que llamamos educación es mucho más que una práctica cuyos resultados suponemos, como expertos, poder predecir en el tiempo. Es una experiencia y un devenir, y en ella, en cada acto educativo, se concitan, quizá, otros modos de actuación, otros gestos, acciones, ejercicios diferentes. Este texto no es más que una primera etapa en esta dirección y, como he dicho, no cierra nada. Apenas quiere dar a pensar algunas cosas, que acaso sean de interés no sólo a los especialistas de la pedagogía, sino para quienes, desde las humanidades, las artes, la música, la literatura, la poesía, la filosofía, el cine, el teatro, y otras disciplinas afines, demuestran cada día, con sus producciones culturales, su vocación educadora y transformadora; una voluntad de pensar y de hacer de otro modo.

Giorgio Agamben $(2015,22)$ dice seguir en sus investigaciones un "principio metodológico", consistente en buscar en los textos o contextos en los que trabaja el «elemento filosófico», es decir, el punto de su máximo desarrollo. Al proceder de este modo, se llega a un punto de indistinción entre autor (o texto) estudiados y el intérprete, lo que genera una dosis de placer intelectual al investigador o estudioso, pero también cierto dolor, porque sabe que ha llegado su hora, la hora del adiós: debe dejar al autor -o al texto estudiado- para seguir por su propia cuenta. Y esto significa que el intérprete-investigador ha necesitado hacerse tan presente en lo estudiado que termina por hacerse parcialmente indistinto de lo que estudia, confiriéndole una especie de segunda piel o naturaleza; como buen discípulo, se ha separado de su maestro, ha tenido que aprender a terminar, a concluir y decirle adiós, para correr su suerte (y su juerga intelectual) con los conceptos por su cuenta. Dicho con toda la modestia del mundo, es precisamente esto lo que al autor de este artículo le ha pasado: he tratado de pegarme a Nietzsche para, a partir de él y contando con su ayuda, tratar de pensar por mí mismo aquello que me interesaba pensar: la educación. 


\section{LA EDUCACIÓN: LO IMPOSIBLE Y LO DESBORDANTE}

Al referirme a lo «imposible» del acto educativo no estoy adoptando una posición nihilista al uso, ni tampoco pesimista. Lo «imposible» es, en rigor, lo único que cabe esperar, porque lo "posible" ya es. Al introducir esta palabra en la educación abrimos otras posibilidades para el lenguaje educativo, un lenguaje de y para la educación. Veamos con un cierto detenimiento esta cuestión.

El trayecto que va de lo posible a lo real se colma de conocimientos, discursos, dispositivos, metodologías, programas o tecnologías de todo tipo. Construye una actividad como una práctica racional previsible en sus resultados. Lo que conduce a lo imposible, en cambio, está fuera de todo orden planificado y organización performativa. Le hablo al otro, aunque no me entienda y, al hacerlo, me lo tomo en serio. Le hablo una y otra vez, y de repente emerge de él o de ella una palabra, da igual cuál sea, siendo, en principio, indiferente que tenga un significado o ninguno. Tiene sentido, si antes nunca dijo nada. Le hablo y hago como si en realidad me entendiese. Se introduce una especie de ficción entre nosotros. Esto es lo desbordante.

Me refiero a lo imposible como algo que nos coloca en la experiencia del tiempo de la espera: tenemos que esperar(nos), y lo imposible no está ahí para que el pensamiento o la acción claudiquen, o para decir "nada puede hacerse ya», sino para permitir que la acción educativa se anuncie según una medida distinta a la del poder o a la del saber preestablecidos. Esta medida, por así llamarla, es la medida del otro y de lo otro en tanto que otro. Le hablo al niño que nunca me responde recíprocamente, que dice cosas que no tienen equivalencia con lo que yo digo, que no son correspondientes a mi saber ni a mi poder; pero al hablarle no le dicto mi saber ni mi palabra. Y precisamente porque espero lo imposible, me abro a un acontecimiento porvenir. Me inscribo, sin saberlo, en un proyecto donde el otro no se fabrica, donde el otro no es el resultado de la aplicación exacta de un programa preestablecido, sino alguien que nace a partir de un encuentro imprevisible y de una fisura que se abre entre los dos. Es a esto a lo que me refiero cuando hablo de lo imposible: no hay que explicarlo todo, no hay que entenderlo todo, no hay que saber siempre lo que pasa entre los hombres y los niños, entre quienes educan y quienes se educan. Lo que pasa entre unos y otros no es un contrato, es un regalo que nos damos. Es un don.

Entendida como don y como regalo, la educación -o sea, lo que pasa en el encuentro educativo- es una experiencia que concierne a dos, pero, simultáneamente también, la ayuda prestada para acompañar al otro al mundo. La educación tiene que ver contigo y conmigo, pero no exclusivamente con nuestras singularidades individuales. La educación, como la política, forma parte de un mundo común. El mundo común trasciende a nuestro tiempo vital, y es lo que compartimos con quienes nos precedieron en el tiempo, con nuestros contemporáneos y también con los que vendrán, en forma de promesa. Pero sólo podrá sobrevivir, como tal mundo común, si somos capaces de encontrarnos las distintas generaciones 
-jóvenes y viejos- y hablar, conversar sobre el mundo para que vuelva a parecer en público a través de las transmisiones.

El sujeto escolarizado se adentra en ese lugar llamado escuela (en griego, scholé, apartamiento temporal del mundo y tiempo libre), y es ahí donde, supuestamente, comienza su aprendizaje, como si lo que ya hubiese aprendido antes y a solas (por sí mismo) -la lengua que habla, por ejemplo- no contase para nada. El asunto al que me refiero tiene que ver con lo que le pasa a una sociedad enteramente pedagogizada, una sociedad en la que todo el mundo explica a todo el mundo: los profesores y los manuales; las instituciones, los ministerios, las comisiones; los comités de expertos, la prensa, la radio, la televisión; las necesidades del mercado laboral: «Este gigantesco sistema de explicaciones trabaja sin tregua para separarnos de lo que vemos y de lo que hacemos, transformando cualquier cosa en un enigma que necesita el auxilio de expertos y comentadores en cualquier materia" (Rancière, 2008a, 20). De este modo, los gobiernos y las clases dominantes se presentan como pedagogos que nos explican el secreto del mundo, del que ellos son los guardianes, yendo siempre un paso por delante de nosotros, a quienes tratan como aprendices con alma infantil que todavía tienen mucho que aprender hasta participar plenamente del mundo. Lejos, entonces, de poder considerar que para la resolución de los «asuntos comunes» la competencia que hay que reivindicar es la capacidad cualquiera (Rancière, 2009), esta lógica reafirma la separación entre creadores y consumidores, sabios expertos e ignorantes inexpertos, emancipadores y emancipados, maestros explicadores y alumnos ignorantes.

Si lo imposible anuncia acontecimientos por venir, lo posible se arraiga en la idea de una potencia que ignora su cara más desventurada: el poder de no hacer. Pero centrémonos ahora en cómo la mutación contemporánea en el lenguaje de la educación tiene bastante que ver con lo que se ha dado en llamar «sociedad del aprendizaje» (Learning Society), la cual insiste, a cualquier precio, en que siempre se debe y se puede. Se trata de un orden social para la cual el impulso a aprender permanentemente y "educarse a lo largo de toda la vida" (Lifelong Education) produce un aprendiz funcional y orientado al éxito, aunque al mismo tiempo perfectamente "alumnizado" e "infantilizado»: una especie de aprendiz eterno.

La conexión entre este orden social y la economía es más que evidente. El premio Nobel de economía Joseph E. Stiglitz (2016) lo deja muy claro en su último libro: observar las políticas económicas a través de las lentes del aprendizaje, advierte, ofrece una perspectiva diferente sobre muchos asuntos que hoy resultan cruciales, pues, para bien o para mal, las políticas gubernamentales tienen efectos directos e indirectos sobre el aprendizaje. Hay que seguir insistiendo, se dice una y otra vez, en la importancia de un "aprender haciendo" (learning by doing, el viejo lema del pragmatismo americano, pero ahora renovado). De este modo, no hay duda de que "la única manera» de aprender lo que se requiere para el crecimiento económico es potenciar el sector industrial, mediante la formación de profesionales en ese campo. Hay que apostar por la competitividad. Educación y tecnología son los pilares fundamentales de la igualdad, se sugiere. Y como educación y 
tecnología van de la mano, la Red es la plataforma de la sociedad del aprendizaje. Ni se duda del hecho de que la eficacia del genuino aprendizaje, el aprendizaje permanente, depende de si sabemos aprovechar las potencialidades de la Red para conectar, comprometer, hacer participar, hacer interactuar tanto a estudiantes como a educadores para facilitar el acceso a los conocimientos y recursos colectivos, dice John Chambers, presidente de Cisco Systems: «La cuestión es adaptar. A pesar del importante papel que cumplieron y seguirán cumpliendo los sistemas educativos tradicionales, estos ya no bastan para satisfacer las crecientes y cambiantes necesidades de aprendizaje del mundo» (Chambers, 2010, 2).

Hemos entrado de lleno, al parecer, en una nueva cultura y en un nuevo lenguaje del aprendizaje -que ha pulverizado un lenguaje de y para la educación-, y que únicamente facilita una comprensión económica del proceso formativo de un sujeto. Según esta lógica, al aprendiz se le exige que sepa de antemano lo que necesita, siendo el mercado educativo quien satisfará sus necesidades. Comprometerse en el aprender ya no entraña la posibilidad de descubrir lo que se necesita (realizar un descubrimiento), sino satisfacer una necesidad ya previa y nítidamente establecida. El nuevo lenguaje económico del aprendizaje torna difícil proponer otras cuestiones y contenidos que no sean los formulados en términos de lo que los clientes o el mercado desean y dictan:

La noción de aprendizaje (y de aprender a aprender) ha llegado hoy a ser la noción central en el discurso educativo y sociopolítico. Por una parte, el aprendizaje tiene que ser considerado como la actividad socialmente más importante de la que depende la supervivencia de los individuos y la sociedad. Por otro lado, la misma realidad pedagógica es objetivada en términos de aprendizaje (y no en términos de Bildung, por ejemplo) (Masschelein, 2001, 12).

¿Quién va a ser el osado, entre los especialistas de la pedagogía, que se oponga a este discurso tan fuertemente blindado sin colocarse, de inmediato, en las filas de los desertores del progreso, sin convertirse en un reaccionario conservador? La apuesta aquí consiste en intentar cuestionar esa lógica economicista de la educación, tratar de explorar otras vías para pensar tanto la educación como el arte del aprender.

No se puede educar sin enseñar al mismo tiempo algo, pues una educación sin aprendizaje es vacía y, por tanto, con gran facilidad degenera en una retórica moral-emotiva. Y, sin embargo, es sumamente fácil «enseñar sin educar», y cualquiera puede aprender infinidad de cosas hasta el fin de sus días sin que por eso se transforme en una persona educada. Muchas de estas cosas tal vez formen parte de los especialistas en pedagogía; pero lo que es competencia de todos -de cualquiera- «es la relación entre las personas adultas y los niños en general o, para decirlo en términos generales y exactos, nuestra actitud hacia la natalidad, hacia el hecho de que todos hemos venido al mundo al nacer y de que este mundo se renueva sin cesar a través de los nacimientos» (Arendt, 2006, 193). En lugar de una libre maduración de la personalidad -como pensaba Nietzsche-, parece imponerse 
una mera acumulación de conocimientos, la acelerada preparación de especialistas y expertos que son tanto más útiles cuanto menos fértiles resultan desde el punto de vista cultural: pues el que participa de la creación cultural siempre busca, indaga, explora: "La finalidad de la educación de los hijos es poner en el mundo hombres más libres de lo que somos nosotros. Ninguna reflexión es tan importante como la tocante a la herencia de las cualidades" (Nietzsche, 2004, verano de 1876, 17 [28], 51).

Me he referido antes a cierta pérdida contemporánea de la idea de la educación como "formación", una pérdida que viene propiciada por el predominio de las voces autorizadas y expertas que componen el discurso de la sociedad del aprendizaje. La conversación educativa está enteramente subyugada por voces expertas y especializadas. En una conversación conducida por voces preeminentes (la de los expertos, los científicos o los técnicos), esas otras voces "menores» constituyen una especie de VOz "suplementaria" (un párergon) difícil de entender. Se trata, como todo suplemento, de una $\mathrm{vOz}$ que se añade a las supuestamente más audibles y autorizadas, pero una que en realidad sólo podrán escuchar los espectadores -como ocurre en el cine que adopta esta técnica-, en vez de los actores del drama que se está desarrollando, quizá porque están excesivamente comprometidos en su papel. ¿En qué consiste este suplemento?

Según Jacques Derrida, el suplemento (o párergon) "no se limita a estar fuera de obra, puesto que actúa también al lado, pegado contra la obra (ergon)" (Derrida 2010, 65). Traducido también como «objeto accesorio", "extraño» o "resto", el párergon se encuentra junto a la obra ya producida, no siéndole entonces ajena, y coopera con ella desde un cierto afuera. Párergon denota, pues, el conjunto de elementos que rodean la obra y desempeñan una función suplementaria. Las "declaraciones del artista" sobre la obra ya realizada complementan su trabajo. Se trata de una "adición" que "completa", y que va hacia donde la obra ya acabada, y que parece hablar por sí misma, en realidad no alcanza. Ese suplemento es, a la vez, un elemento complementario y compensatorio: no se trata de algo que se pueda eliminar tan fácilmente.

La voz autorizada y experta, que dice la educación y la nombra, que establece lo que hay que aprender y cómo, que define los plazos, los ritmos, que evalúa los resultados y mide, quedaría, según lo que pretendo sugerir aquí, completada, pero además corregida, incluso quizá desmentida, por voces suplementarias que, lejos de consistir en un comentario ampliado sobre lo ya dicho, y que proviene de tales voces expertas, emana del otrolado. Son su extrañeza y su radical alteridad. Estas voces irrumpen e interrumpen: irrumpen en lo ya dicho e interrumpen su curso; es una voz visitante y extranjera; una especie de voz en off.

La VOz de Nietzsche, al introducirla en esta conversación educativa enteramente dominada por voces expertas, abre una grieta en su seno por la que se cuelan algunas cosas. Probablemente con la voz de Nietzsche asistimos al nacimiento de una reflexión sumamente incómoda para buena parte del pensamiento y la filosofía contemporáneas, también para la pedagogía. Pues para Nietzsche el 
objetivo de la cultura es educar al animal humano para liberar en él una segunda naturaleza o una especie de naturaleza más natural. Criticando las instituciones de la cultura de la Alemania de su tiempo, percibe que la educación no es sino un sistema de medios para arruinar las excepciones a favor de la regla: "La educación: un sistema de medios para arruinar la excepción a favor de la regla. La formación: un sistema de medios para disponer el gusto contra la excepción, a favor de los mediocres» (Nietzsche, 2009, 16 [6], 672). En muchas de sus afirmaciones, Nietzsche puede resultar excesivo, y ya se ha vertido suficiente tinta como para tener que demostrar aquí -entre otras cosas porque no es el objetivo del presente ensayoque Nietzsche no es un precursor del nazismo; «una cosa soy yo y otra son mis escritos", solía decir (Nietzsche, 2011b, 72). Así que conviene leerlo con cautela, sí, pero también con respeto intelectual, lo que no siempre se hace, evitando descontextualizar fragmentos de su obra, y distinguir adecuadamente la perspectiva desde la cual se analiza; pues sabemos que desde una interpretación antipolítica es fácil acusarle de ser el precursor de ideologías totalitarias, así como desde una óptica apolítica representárnoslo, en cambio, como un perfeccionista moral alineado con las democracias liberales. Seguramente una opción más equilibrada sería leerlo desde la perspectiva de la democracia radical, como ha mostrado Vanessa Lemm $(2013,21)$. Por tanto, es preciso tomarse en serio lo que Nietzsche dice, "pero no al pie de la letra" (Kouba, 2009, 15). El mismo Nietzsche lo advierte en una carta a Carl Fuchs: «No es necesario ni deseable que alguien tome partido por mí. Al contrario, una dosis de curiosidad, como la que nos inspira una planta extraña, acompañada de una resistencia irónica, me parecería una posición incomparablemente más inteligente en relación a mi persona» (Friedrich Nietzsche, carta a Carl Fuchs, 29 de julio de 1888, citado por Safranski, 2002, 15).

\section{LA PEDAGOGÍA COMO FILOSOFÍA}

Hablar de la educación en los términos descritos -como encuentro con uno mismo, con la vida y con el mundo- nos conduce a una antigua concepción de la filosofía según la cual filosofar es aprender a vivir (un arte del saber vivir y morir), y, en sí misma, un modo de educación, una cierta Paideia (cf. Foucault, 2005; Hadot, 2006, 23-78; Greisch, 2015; Lorenzini, 2015; Nehamas, 2015; Pavie, 2012). Sólo la filosofía, en su sentido fundamental y primigenio, educa, porque transforma. La filosofía, dirá Nietzsche en La filosofía en la época trágica de los griegos, tal y como los presocráticos la practicaron, como una contemplación del mundo, es una "manera de vivir y considerar las cosas humanas" (Nietzsche, 2011a, 571).

En efecto, en el mundo de la Grecia clásica la filosofía consistía en una transformación del individuo, y el filósofo era un educador que acompañaba y conducía las almas de los jóvenes discípulos que tenía a su cargo. En este contexto, elegir ser un filósofo no era elegir una profesión, sino que se trataba de una elección existencial. Con todas sus limitaciones e inconvenientes -en una sociedad enteramente masculina donde la esclavitud era admitida y, por tanto, las desigualdades 
sociales- los griegos lo tenían claro. Como recuerda en uno de sus cursos Foucault comentando algunos textos de Séneca:

La vida entera es una educación. Y la epimeleia beautou (cuidado, inquietud de sí), llevada ahora a la escala de la totalidad de la vida, consiste en que uno va a educarse a sí mismo a través de todas las desventuras de la vida [...] Debemos educarnos perpetuamente a nosotros mismos, a través de las pruebas que se nos envían y gracias a esa inquietud de sí mismo que hace que las tomemos en serio. Nos educamos a nosotros mismos a lo largo de toda la vida y la formación es la primera característica de la vida como prueba (Foucault, 2005, 210).

Toda la filosofía antigua era, entonces, una especie de ejercicio espiritual, expresión que designa toda práctica destinada a transformar, en uno mismo o en otros, la manera de vivir y de ver las cosas; al mismo tiempo que un discurso (interior o exterior) es una puesta en obra, una realización, una praxis vital. Una disciplina (un ejercicio) destinada a vivir mejor y orientada hacia un mejor ser. Afirmaciones como estas desexpertizan -permítaseme la expresión- el saber pedagógico, y eso es precisamente lo que más enoja a ciertos discursos pedagógicos con vocación de profesionalización de la actividad educativa. El principal objetivo de las escuelas filosóficas griegas no consistía en la elaboración de una teoría, sino en dotar al individuo de la capacidad necesaria para poder vivir de forma distintivamente mejor su existencia en relación con los demás y las contingencias y fragilidades de la vida. El acceso a la verdad dependía de la transformación individual del sujeto, del trabajo que el individuo realizase sobre sí mismo (epimeleia heautou). Ese trabajo comprometía una relación psicagógica entre maestros y discípulos y un verdadero "ejercicio espiritual", en el sentido griego del término. De nada vale decirle a alguien que existe una verdad ahí afuera, inamovible y universal, que puede conocerse si uno aplica la razón como es debido si no aprende a cuidar de sí, ejercitándose. No pretendo idealizar este mundo, sino inspirarme en algunas de sus noticias. Lo que en el fondo pretendo hacer, con la ayuda de Nietzsche, es pensar la formación - ¿es todavía pensable esta palabra sin recurrir a cierta idea de la cultura?- desde una concepción de la pedagogía como filosofía.

No se trata de disolver el género "pedagogía" en el género "filosofía", pero tampoco de fortalecer ningún tipo de orden discursivo que nos impida la conversación entre ambas. Sus historias respectivas no merecen tal desencuentro. Muchos temen un cierto fin de la pedagogía cuando se estrechan los lazos entre ella y, por ejemplo, lo poético, lo literario o, en este caso, lo filosófico. Se concede cierto papel a la filosofía (incluso como "filosofía de la educación") porque se supone que la pedagogía encuentra sus fundamentos en ella, como también en la antropología y en otras disciplinas. Estrategia que termina por hacer de la filosofía de la educación una mera disciplina aplicada, cuando no un conocimiento marginal y del todo asimilable -es decir: eliminable- a la denominada teoría de la educación.

Similarmente a lo que ocurre con la polémica entre filosofía y literatura -tras la cortés invitación de Platón a que los poetas abandonen la ciudad (Murdoch, 
2016)_ ${ }^{3}$, también en nuestro campo suponer el "fin de la pedagogía», al permitir la entrada en su seno de lo filosófico, parece ignorar hasta qué punto siguen estando justificadas las diferencias entre géneros filosóficos, literarios o pedagógicos (Sánchez-Meca, 2016, 10). Del mismo modo que el término "filosofía» quizá ya no designa, desde la crítica a la Metafísica occidental, un discurso distinto del literario -pues, como ocurre con la literatura misma, esta misma también implica el arte de escribir en general-, también la pedagogía consiste en un cierto arte de pensamiento y de escritura que no tiene por qué perder su entidad por nutrirse del pensamiento filosófico. En pedagogía, como en filosofía, se trabaja con un lenguaje que produce cultura, y ésta se genera tanto en la creación poética como en la novela, el ensayo, el teatro, y también en filosofía y pedagogía.

Y es que la pregunta por la educación no es un tipo de pregunta exclusivamente pedagógica, sino una que es filosófica en su misma raíz. Y la pedagogía, cada vez que se pregunta: "¿qué es la educación?», se ve obligada a adoptar una mirada filosófica, y entonces se reencuentra con su origen. También es cierto que toda educación, y todo aprender, compromete un viaje -la misma palabra educación lo dice: «salir afuera» (educere) - sólo que ese viaje no es, como podría pretenderse, un viajar cuya entera organización dependa exclusivamente de la pedagogía, concebida como saber experto (Morice, 2016). Volveremos más tarde sobre esto.

\section{EdUCACIÓN INTEMPESTIVA: APUNTE SOBRE NiETZSCHE}

Al decir lo anterior estoy estrechando los vínculos entre pedagogía y (una cierta idea de) la cultura. Una cultura que se arraiga en la vida y la piensa, como piensa el mundo, con todas sus ambivalencias y contradicciones incluidas.

Es eso precisamente lo que pensaba el joven Nietzsche, a quien en 1869 se le concede la cátedra de Filología en la Universidad de Basilea, asignándosele dos tareas centrales, cuya relación percibe como problemática: la investigación de la cultura antigua y la educación de las nuevas generaciones. Nietzsche refiere muchas de sus reflexiones de esta época a la filología, y sugiere que es una disciplina incapaz ya de asumir su tarea educadora. Sus dudas las resumirá en su inacabada intempestiva Nosotros, los filólogos, que reúne los fragmentos póstumos correspondientes al invierno de 1874 y verano de 1875. El planteamiento de Nietzsche que me gustaría rescatar aquí se concentra en un aforismo de la primavera-verano de 1888, donde diferencia entre civilización y cultura en los términos siguientes:

Las cimas de la cultura y de la civilización se hallan separadas las unas de las otras: no debemos dejarnos engañar sobre el abismal antagonismo entre cultura y civilización. Los grandes momentos de la cultura siempre fueron, hablando moralmente, tiempos de corrupción; y, por su parte, las épocas de forzada y querida

3. Platón narra la expulsión de los poetas, como se sabe, en la República (Platón, 2003, x, $607 \mathrm{ab})$ 
doma ("civilización") del ser humano fueron tiempos de intolerancia para con las naturalezas más espirituales y más osadas. La civilización quiere una cosa diferente de lo que la cultura quiere: quizá una cosa contraria (Nietzsche, 1888, 16 [10], 673).

La contraposición entre "cultura" (Kultur) y "civilización» (Zivilisation) remite al argumento de fondo de que quien se opone a la cultura es el "hombre civilizado". El civilizado es ahora el bárbaro, el inculto, y los precedentes de esta polémica se encuentran, entre otros, en el conservador Max Stirner (2013) -que influyó en Nietzsche- y en la discusión que en torno a 1810 tuvo lugar en Alemania sobre el modelo educativo universitario, y en concreto sobre la Universidad de Berlín, fundada por Humboldt en 1810.

En 1889, Nietzsche dirá todavía que «al sistema entero de educación superior en Alemania se la ha ido de las manos lo principal: tanto la finalidad como los medios de lograrla. Se ha olvidado que la educación, la formación misma -y no el Reich- es la finalidad, que para lograr esa finalidad son precisos educadores -y no profesores de Instituto y doctos de Universidad" (Nietzsche, 2013, 104). Un escritor como Thomas Mann también se mueve cómodamente dentro de esta polémica; basta leer sus Consideraciones de un apolítico -un libro en el que cita a Nietzsche- para advertirlo; por ejemplo, su crítica a los, así denominados despectivamente por él, "literatos de la civilización» (Mann, 2011, 65-79). Como tantos otros alemanes de la época, Mann se considera un «alemán genuino", alguien que -como sugiere Sánchez-Meca (2016, 145) - jamás ha admitido el elemento político en su concepto de Bildung; Mann sería entonces un decadente que, sin embargo, lucha por salir de su decadentismo, y que asume con todas sus contradicciones incluidas.

El compromiso con lo político es, bajo esta óptica, el desvío de una interioridad que busca forjarse y que, a su vez, se construye un refugio y permite un exilio autoelegido: «[E]l ideal de la Bildung favorece e intensifica la ruptura entre el ser (riqueza interior) y el tener (dinero). No es de extrañar, por tanto, que muchos críticos de la sociedad burguesa-capitalista sean alemanes»(Sala Rose, 2007, 136); o como anota Wolf Lepenies, y esto sirve tanto para Alemania como para otros países: "La cultura ha funcionado como substituto de la política en muchas épocas y lugares» (Lepenies, 20008, 17). La interioridad, entonces, como una búsqueda espiritual y estética que deliberadamente se mantiene al margen de la acción política (sabemos, sin embargo, que tras la llegada de Hitler al poder, el propio Thomas Mann, que nunca abdicó de sus posiciones filosóficas y políticas originales, se comprometería activamente contra el nazismo). La novela de Romain Gary Europa refleja muy bien este tipo de personalidad que construye la Bildung como un humanismo que tiene el deber de analizarlo todo a distancia -espiritualde las controversias de un mundo agitado. Jean Danthés, el personaje principal, embajador de Francia en Roma, es un hombre de inmensa cultura, demasiado embebido de cultura, que «vivía en comunión constante con ella, refugiándose en el arte, experimentaba casi continuamente un sentimiento de irrealidad, de vacío, de ausencia” (Gary, 2010, 25). 
Este antagonismo entre cultura y civilización representa un enfrentamiento entre fuerzas vitales humanas y animales: mientras la cultura se define como cultivo y promoción de la vida, la civilización, según Nietzsche, es domesticación y cría. El proceso de civilización aspira al mejoramiento del ser humano, y constituye según él un proceso de índole moral que impone por la fuerza y la voluntad una costumbre: "Ser moral, tener buenas costumbres, ser virtuosos, quiere decir practicar la obediencia a una ley y a una tradición fundadas desde hace mucho tiempo. Que nos sometamos a ella de buen o mal grado, es cosa del todo indiferente; basta con que lo hagamos" (Nietzsche, 2015a, af. 96, 95). La tarea de la cultura es, sin embargo, otra. Tiene, primero, una función crítica: mostrar que la racionalidad y la moralización son en el fondo técnicas de dominación dirigidas contra la animalidad del ser humano. Así, la cultura revela que las mejoras de la civilización son en el fondo falsas superaciones que encubren un anhelo de doma, bajo el pretexto del mejoramiento del ser humano; y, segundo, una función de liberación: su tarea es la de imponerse frente al dominio de la civilización, es decir, suscitar formas de vida que no se conviertan en formas de poder sobre la vida, sino que sean formas rebosantes de vida. Estas formas rebosantes de vida la cultura las recupera o las recrea, en los sueños, en las pasiones que derivan de los instintos humanos. La civilización europea se ha desarrollado, dirá Nietzsche, desde la desconfianza hacia lo vital y desde un desprecio ascético hacia los estados corporales (Lemm, 2010, 38).

Cuando la cultura llega a un punto culminante, domina a la civilización, pero cuando es la civilización la que llega al punto máximo, ésta domina a la cultura. En su punto de desarrollo máximo, la civilización se manifiesta como un acto de violencia dirigida contra la animalidad del ser humano y como intolerancia frente a las naturalezas más audaces y espirituales. Pero lo que define la cultura es su libertad frente a la moralización, entendida como domesticación que impone la civilización. El ideal ascético -la idea de la ascesis como "renuncia", no como «ejercitación»-, dirá Nietzsche en La genealogía de la moral, le ha servido al filósofo como carta de presentación: "Como presupuesto de su existencia [...] La actitud apartada de los filósofos, actitud peculiarmente negadora del mundo, hostil a la vida, incrédula con respecto a los sentidos, desensualizada" (Nietzsche, 2006, III, 10, 197). Por supuesto, Nietzsche está hablando del metafísico, del filósofo que, en todo caso, ha sustituido la búsqueda de la cultura por los ideales de la civilización, inscritos en una moral negadora de la vida.

Bajo el dominio de la cultura, el animal humano olvida las normas morales y racionales de la civilización -pero no para hacer, como vulgarmente se dice, de su capa un sayo; a Nietzsche le preocupa una ética no moralizante, una ética que no olvide que "únicamente de la vida puede crecer y brotar la cultura» (Nietzsche, 2003, 131): «El moralizador es el que se preocupa por la virtud de los otros y por la obediencia escrupulosa a las reglas. Una ética no moralizante estaría basada, en cambio, en la confianza en la verdadera autonomía del otro» (Sánchez-Meca, 2015, 87). Esa ética, para Nietzsche -y ese es un aspecto bien problemático de su posición moral-, es una cuestión de "estilo", de refinamiento en el comportamiento, y mantendría una 
fuerte relación con la estética: anhelo de bellas y nobles acciones por amor de sí y no por respeto a una regla universal a priori. Es de aquí desde donde también se alimentará la ética como una estética de la existencia en Foucault ${ }^{4}$.

La civilización es una especie de olvido de sí (de lo animal e instintivo del hombre), pues es gracias a este olvido como resulta posible el nacimiento del animal humano en tanto que humano, y donde los seres humanos pueden entenderse a sí mismos como seres racionales y morales. Pero este comienzo trae como consecuencia la degeneración de la vida humana y de la cultura. La civilización desvincula al ser humano de su inicio animal, produciéndose un vacío que la civilización misma tratará de llenar mediante la ficción de un relato según el cual el mundo es una especie de orden moral y racional. En ese punto, los discursos de la civilización y del cristianismo comparten su interés por el mejoramiento moral del ser humano a base de control y procesos de domesticación pastoral del rebaño:

Llamar a la domesticación del animal 'mejoramiento' suena a nuestros oídos casi como una broma. Cualquiera que sepa lo que sucede en una casa de fieras dudará que en ellas la bestia 'mejore'. Es debilitada, es hecha menos dañina, es convertida, mediante el efecto depresivo del miedo, mediante las heridas, mediante el hambre, en una bestia enfermiza. -Lo mismo ocurre con el humano domesticado que el sacerdote ha 'mejorado'- (Nietzsche, 2013, 94).

El nuevo lenguaje del aprendizaje del que antes hablábamos parece, en este sentido, enteramente fundado en una imagen de la "persona educada» que instituye una especie de maquinaria antropológica según la cual lo «humano» se forja contra lo "no humano» que hay en nosotros: nuestra parte animal, es decir, no moral y no racional. De modo que lo que llamamos "ser humano educado" no es sino el "Sujeto civilizado", donde la "civilización" ha establecido un pacto con el olvido: el olvido del comienzo animal de lo humano. El «afuera» de lo humano se produce (y esto significa que, en rigor, "se fabrica»), dirá Agamben $(2005,52)$, por medio de un dispositivo de exclusión de algo que está dentro (nuestra parte animal), de modo que lo inhumano se construye como animalización de lo humano, lo que produce una serie de imágenes que históricamente están bien documentadas: semi-hombre, enfant-sauvage, Homo Feres; pero, igualmente: esclavo, bárbaro, extranjero, y

4. La relación entre ética y estética, la posibilidad misma de una ética como estética de la existencia -el mismo Foucault lo dice en sus cursos y entrevistas- puede ser acusada de cierto aristocratismo, de cierto dandismo esteticista, à la Oscar Wilde, y de producir individuos, como antes dijimos en relación a la polémica entre Kultur y Zivilisation, desapegados de la política y, en ese sentido, también ajenos a las miserias y sufrimientos del mundo. Algunos pueden llegar a decir que hay demasiado "yo", demasiada "subjetividad" o demasiado "ego" y olvido del otro en semejante ética esteticista. Sobre esto, hay que recordar lo que el mismo Foucault decía: «En lo que podríamos llamar el culto contemporáneo de sí, el objetivo es descubrir el verdadero yo propio, separándolo de lo que pueda oscurecerlo o alienarlo y descifrando su verdad gracias a un saber psicológico o un trabajo psicoanalítico. Por eso, no solo no identifico la cultura antigua de sí con lo que podríamos llamar el culto contemporáneo de sí, sino que creo que son diametralmente opuestos» (Foucault, 2015, 361). 
tantas otras que obligan a la buena conciencia democrática a poner el corazón en el centro de la política e introducir en ella una piedad jerarquizada que se camufla con el nombre de compasión (D'Allonnes, 2008).

La crítica nietzscheana a la educación tiene que ver, pues, con la crítica a la destrucción de lo singular, único e irrepetible del individuo en pos de una masificación. En este sentido, Nietzsche es un crítico feroz de un modelo de estudiante funcional, un estudiante domesticado que el sistema engulle y normaliza. Contra la idea de este estudiante moderno y funcional, Nietzsche recomienda un estudiante inactual, intempestivo, uno que sea, a la vez, joven y viejo, inscrito en la temporalidad natural del crecimiento. Nietzsche insiste reiteradamente en esta idea: la instrucción pedagógica surge como un sistema de medios para orientar el gusto en favor de los mediocres; o lo que es igual: masificación del individuo. La enseñanza, dirá en Sobre el porvenir de nuestras escuelas, de 1872, constata dos tendencias contrapuestas: una tendencia orientada a la máxima extensión de la cultura general, por un lado, y, por otro, una tendencia a disminuirla y debilitarla, orientando la cultura al servicio de la forma de vida del Estado (Nietzsche, 2001, 24-25). De acuerdo con estas dos tendencias, el propósito pedagógico será insertar al estudiante en una práctica social de trabajo, en el régimen de la utilidad y de la funcionalidad. En este sentido, la enseñanza moderna, que reivindica el acceso de todos a la cultura, lo que en realidad está practicando es una hostilidad hacia la verdadera cultura (la del genio). La educación de la juventud se funda entonces en una mentira: al mismo tiempo que se afirma la existencia de un pasado y una cultura, las instituciones se limitan a formar especialistas, caricaturas de hombres sabios (filisteísmo cultural). En realidad, pues, no tenemos una cultura: somos simplemente seres civilizados. Si la civilización doma, la cultura es una tarea de individuos «incómodos", porque su objetivo es la grandeza, no la felicidad.

La posición de Nietzsche con respecto a la educación depende enteramente de su crítica de la cultura. Para él, la verdadera liberación del hombre no se alcanza, como hemos visto, abandonando la animalidad, sino superando formas demasiado bumanas de moralidad y de racionalidad. Nietzsche niega la creencia en el progreso, pero, al mismo tiempo, tampoco aboga por el retorno a una naturaleza originaria, ni propende un regreso romántico a un supuesto origen más elevado o más puro. En realidad, aunque con otros argumentos, él también, como Platón, expulsa a los poetas románticos de la ciudad, porque mienten demasiado, aunque no lo dicen. Así pues, lo que Nietzsche pretende es estudiar la cultura, no como un fenómeno racional y moral, sino como un fenómeno de la vida. Lo interesante de la cultura no es que a través de ella el ser humano se libere o se emancipe de la animalidad, sino justo todo lo contrario: que se reencuentre con ella.

Por eso, para la reflexión de Nietzsche sobre la educación el núcleo fundamental es el encuentro, la relación, entre el maestro y el discípulo, una relación problemática pues supone una articulación paradójica entre la autoridad de aquél y la autonomía del discípulo. ¿Cómo educar en ausencia de una cultura que refuerce la vida? ¿Cómo educar cuando ya no hay maestros (creadores de cultura) sino 
simplemente profesores (transmisores de moralidad)? ¿Cómo educar si los profesores no son, ellos mismos, educados? En un mundo enteramente volcado a la acción, más que a la contemplación, la reflexión y el pensamiento: ¿cómo hacer posible el acto educativo, si lo único que interesa es producir especialistas y expertos? Para el viejo maestro de las conferencias Sobre el porvenir de nuestras escuelas, la adquisición de la cultura (Bildung) consiste en una apropiación personal de las huellas vivas del pasado de los pueblos. Todo reside en la cuestión de esa vitalidad y de su articulación con las fuerzas vivas de la juventud. Poner a los jóvenes en contacto con ese pasado vivo es volverles inactuales, intempestivos, anacrónicos. Y de eso se trata: de que no den el salto por encima de la cultura para insertarse en el medio social y del trabajo. Se trata de transformarles en lo que son: en individuos.

Si alguien se preguntase por el modelo educativo que Nietzsche reivindicaría, la respuesta es mucho más fácil de responder de lo que imaginamos. Se trataría de algo, en verdad, anacrónico, como no podía ser de otro modo: una comunidad de amigos, de verdaderos espíritus libres, formando escuelas filosóficas al estilo de los griegos. Si un verdadero deseo de libertad y emancipación pasa por ir contra la historia, una escuela à la Nietzsche no podría ser de otro modo. De hecho, fue una idea que no dejó de acariciar desde su viaje a Sorrento, en 1876. Anhelaba hacer una escuela de educadores donde se educara a los educadores mismos, para que estos se educasen a sí mismos. Un escuela «donde está el médico/el biólogo/ el economista/el historiador de la cultura/el especialista en Historia de la Iglesia/el especialista en los Griegos/el especialista en el Estado»:

La escuela de los educadores surge en razón de la evidencia de que nuestros educadores no están educados ellos mismos; de que cada vez es mayor la necesidad que se tiene de ellos, y su calidad, cada vez menor; de que debido a la natural compartimentación de los ámbitos de trabajo, las ciencias apenas pueden evitar la barbarie en el individuo; de que no hay un tribunal de la cultura que, al margen de los intereses nacionales, evalúe la buena marcha espiritual de todo el género humano: un ministerio internacional de educación.

Quien como espíritu libre quiera emplear bien su dinero, debe fundar institutos conforme al estilo de los conventos, para posibilitar una convivencia amigable en medio de la mayor sencillez con aquellas personas que no quieran tener nada más que ver con el mundo (Nietzsche, 2007, 17 [50], 250).

\section{LA EDUCACIÓN ENTRE LAS GENERACIONES}

Ya dijimos más atrás que en su segunda intempestiva Nietzsche recurre a la juventud, a la que habla, desde la que habla, y con la que necesita contar para una entera renovación de la educación y la cultura. Es cierto que el punto más débil del pensamiento temprano de Nietzsche reside en que, llevado por el desprecio de su tiempo y el reconocimiento de sus modelos, en realidad lo que hace es dar forma a un ideal. Y este ideal cultural parece fundarse en la diferencia entre hombre de a pie, no culto, y genio. 
Pero lo que interesa destacar ahora es el hecho de que, al apelar Nietzsche a la juventud, nosotros podemos encontrarnos en el centro de su filosofía (de la educación) aquello que es del todo central y hoy parece casi enteramente olvidado: la relación educativa entre las generaciones. Lo que le preocupaba a Nietzsche es la mentira en la que se fundaba la educación de los jóvenes. Seríamos, los educadores, los últimos depositarios de la cultura del pasado y, sin embargo, dice, sólo se forman eruditos, especialistas, profesionales (justo como ahora). En su escrito Aurora, de 1881, Nietzsche introduce un aforismo sobre "Los loadores del trabajo", que merece ser transcrito, por su enorme actualidad:

En la magnificación del trabajo, en el incansable hablar de la «bendición del trabajo", veo la misma idea oculta existente en la alabanza de las acciones impersonales de interés general: las del temor a todo lo individual [...] Pues consume una energía nerviosa tan extraordinaria que se le arrebata a la reflexión, a la meditación, al sueño, a la preocupación, al amar, al odiar, coloca siempre en el punto de mira un objetivo pequeño y otorga livianas y regulares satisfacciones [...] ¡Precisamente el «trabajador» se ha vuelto peligroso! ¡Hay un pulular de individuos peligrosos! Y tras de ellos el peligro de peligros: jel individuo! (Nietzsche, 2006, af. 173, 217).

En Nietzsche atisbamos entonces una filosofía, y una política que, en relación a la educación, busca la verdadera emancipación del individuo (Astor, 2014, 114115), la transformación del hombre en individuum. Siguiendo este hilo, vamos ahora a tratar de profundizar en lo que puede significar ese encuentro entre generaciones.

\subsection{Encuentro entre generaciones}

Hannah Arendt definió la esencia de la educación como natalidad, como un acto cuya experiencia encuentra su razón de ser en la llegada al mundo de los nuevos, que son recibidos por los que ya estaban en él. Todo nacimiento está colocado bajo el signo del inicio o del comienzo: los hombres, aunque han de morir, no han nacido solo para eso, sino para comenzar. De este modo, la infancia, como expresión de lo recién llegado al mundo, es la potencia de lo nuevo, y por eso la educación tiene que ver con la manera como recibimos -los que ya estábamos en el mundo- a los recién llegados. En definitiva, la educación es una relación entre mortalidad y nacimiento. Aquí reside la raíz de todo compromiso educativo: un compromiso con las vidas que nacen y llegan; un compromiso con el mundo.

La fórmula «encuentro entre generaciones en la filiación del tiempo» viene a señalar un aspecto que es central en toda experiencia educativa, a saber, que el vínculo educativo define un encuentro entre dos tiempos: un tiempo adulto y un tiempo joven, un tiempo que comienza o se inicia en el mundo. No hay experiencia educativa sin deseo o voluntad de influencia, y sin la presuposición de que el otro con el cual nos encontramos en la escena educativa es influenciable de algún modo; que es mejorable, y por la misma razón también empeorable, por así decir. 
Pero resulta que entre lo que esperamos lograr y lo que finalmente termina sucediendo se abre un abismo. Nadie sabe de antemano lo que pasará al final. Como le pasó al pedagogo Joseph Jacotot en 1808, en su experiencia de Lovaina como profesor de francés que era de un grupo de estudiantes que no podían comunicarse sino en holandés, como él no podía hacerlo en otra lengua que no fuera el francés. Con la única ayuda de una versión bilingüe de Las aventuras de Telémaco, de Fenelón, y una consigna -aprenderse el texto francés ayudándose de la traducción- los resultados fueron asombrosamente buenos.

Y es que existe esa imprevisible libertad que define todo encuentro humano. Intervenimos y experimentamos educativamente una situación no porque sepamos de antemano qué hacer, sino precisamente porque lo ignoramos. Nos entrometemos en el otro y le ofrecemos cosas que no tienen que ver ni con sus necesidades iniciales ni con lo que socialmente se demanda o con lo que el mercado impone. Desbordamos el acto, y nos desbordamos en él. Se dan cosas -y en esto consiste hacer un regalo-, precisamente porque no se necesitan, y porque al establecer el encuentro educativo nos pasan cosas que no habíamos previsto y, entonces sí, nos reencontramos, como aprendices, con las necesidades que no sabíamos que teníamos y que son las que verdaderamente cuentan. Así, la experiencia educativa es impredecible en sus resultados, irreversible en sus efectos, un medio sin fin ni destino predeterminado, un vínculo que une a dos generaciones que pertenecen a dos tiempos distintos y que aprenden a amarse en un encuentro inédito y desbordante. Se trata de una promesa de transformación cuyo rumbo y devenir se desconoce de antemano. La educación está fuera de toda medida: es lo que, contando, porque vale la pena, está fuera de toda cuenta, de toda aritmética. No hay medida (Antelo, 2005). Y es esta falta de medida la que nos debería empujar, como dice Carlos Skliar, a "prestar una atención más escrupulosa a las máscaras institucionales con las que se pretende regular, administrar y, muchas veces, destruir la conversación educativa» (Skliar, 2014, 205).

Todo esto explica por qué la educación es un encuentro o un tipo de relación que se resuelve en un acto de transmisión (transmitir es trasladar, hacer pasar algo de un tiempo a otro tiempo), y que ese encuentro se ofrezca en el tiempo. Tiempo en el que perderse y aprender a hacer un buen uso de uno mismo, no simplemente de lo que se nos enseña. Se trata, entonces, de ejercitar la conversación entre las generaciones. Pues sin conversación no hay educación. Una conversación abierta en la que siempre hay voces dominantes y voces más conversables que otras, porque no están seguras de ninguna verdad. Como seres «educables» somos los herederos de una conversación antiquísima que comenzó muchísimo antes de nuestro nacimiento. Educarse en el curso de esta conversación significa aprender los hábitos, intelectuales y morales, para participar de ella, para encontrar los momentos oportunos para intervenir, y para la escucha. No se trata de una disputa, ni es un debate, ni se trata de hacer congresos entre especialistas. Se trata de conversar, cuando conversar no supone tener que llegar a un punto de acuerdo al cual ya se había previsto debía llegarse. Una conversación presidida, no por un saber 
ya adquirido, sino por una voluntad de saber que nos instala en nuestras ignorancias y busca articularlas, tomando conciencia de ellas.

\subsection{Elogio del tiempo libre}

En el prefacio a su libro Entre el pasado y el futuro, Arendt se refiere a una parábola a la que alude para pensar la brecha que hay entre dos instancias del tiempo: el pasado y el futuro. En la parábola de Kafka, alguien llamado "Él» es empujado por dos fuerzas contradictorias: una le espolea por detrás -con la fuerza del pasado- y la otra desde delante, con la presión que ejerce el futuro. En medio está Él, en un campo de batalla en el que las fuerzas del pasado y del futuro se enfrentan, de modo que si ese alguien llamado Él quiere mantenerse firme ha de enfrentarse también a ellas, en su propio presente, con la máxima resistencia:

Tiene dos enemigos: el primero lo amenaza por detrás, desde las fuentes; el segundo le cierra el camino hacia adelante. Lucha con ambos. En realidad, el primero lo apoya en su lucha contra el segundo, quiere impulsarlo hacia adelante y de la misma manera el segundo lo apoya en su lucha contra el primero, lo empuja hacia atrás. Pero esto es solamente teórico. Porque aparte de los adversarios también existe él, ¿y quién no conoce sus intenciones? Siempre sueña que en un momento de descuido - para ello hace falta una noche impensablemente oscurapuede escabullirse del frente de batalla y ser elevado, por su experiencia de lucha, por encima de los combatientes, como árbitro (Kafka, 1953, 245).

Arendt llama la atención sobre esta parábola porque lo que quiere pensar es el pensamiento bajo sus coordenadas estrictamente contemporáneas. Deseo traer a colación aquí este relato para tratar de pensar esta fórmula desde el punto de vista de cierta consideración de la educación muy alejada de la visión que he tratado de ofrecer en algunos momentos de las líneas precedentes.

En casi todas sus modalidades -y esto es algo que se puede rastrear a lo largo de la historia de las ideas pedagógicas-, la educación, bajo el formato de la escuela, está en el centro de esas fuerzas en contradicción, en medio de un campo de batalla que amenaza constantemente con destruirla: entre la presión de unas tradiciones a menudo consideradas insostenibles y la de los dueños del futuro, que se empeñan en programar cómo debe ser lo que todavía no es. De este modo, pensar la educación "entre» el pasado y el futuro supondría tratar de pensarla bajo el signo de un gesto de resistencia que se ejerce desde el propio presente. No es huyendo del presente como construimos la conciencia de lo que somos, sino afrontándolo, inmiscuyéndonos en él, haciéndonos presentes en cada aquí y en cada ahora.

El tiempo en el que se enmarca el vínculo educativo es el tiempo vital y biográfico (destinado a colmarse de experiencias) de cada uno de los integrantes de la relación (adulto/joven); pero se trata, también, de una experiencia de la duración. Mi percepción es que, hoy, ese tiempo -el tiempo de la escuela, el tiempo de los estudios, el tiempo del enseñar y del aprender, el tiempo de la educación- se ha 
convertido en un tiempo medido y, poco más o menos, reglado, reglamentado y cronometrado. Es un tiempo sometido a forma y enmarcado en una cuadrícula. No es un tiempo libre -el tiempo de los hombres libres-, un tiempo en que quepa hacer cualquier cosa, sino un tiempo esclavo, limitado, y además sometido a incesantes y ridículas evaluaciones de resultados. (Preguntar ¿en qué has invertido tu tiempo? es cómo decir ¿en qué título has invertido tu dinero, en qué acciones?).

Hay, pues, un tiempo esclavo y un tiempo libre (no sorprende que hoy hasta el tiempo libre haya dejado de serlo, bajo el formato pedagógico de la organización del ocio y del tiempo libre). En un momento del diálogo platónico Teeteto, Teodoro le pregunta a Sócrates «Es que no tenemos tiempo libre, Sócrates?» (172c). La conversación que estaban manteniendo ha tomado un inesperado giro, y Sócrates le advierte que de seguir la vía que se ha abierto les llevaría demasiado lejos, de ahí la pregunta de Teodoro. En todo caso, Sócrates le dice algo: los filósofos disponen de tiempo (libre) para componer sus discursos "en paz y en tiempo de ocio" (172d-e). A diferencia de los discursos que se desarrollan en los tribunales, que está medido por el reloj de agua de Clepsidra, que medía el tiempo en ellos, los filósofos hablan sin medida. Comentando este diálogo, José Luis Pardo observa que "lo que convierte al tiempo en esclavo es precisamente la actitud de los esclavos (del tiempo) hacia él ("siempre hablan con urgencia del tiempo pues les apremia el flujo constante del agua”)" (Pardo, 2004, 111).

Así, en la medida en que, por ejemplo, los estudios universitarios se han volcado, casi unilateralmente, hacia la profesionalización (la educación no sirve para formarnos, sino para encontrar un trabajo, y todo trabajo tiene un ciclo de inicio y de fin, de comienzo y resultados, de entradas y salidas "a la hora»), el tiempo educativo ha devenido un tiempo esclavo. Ha dejado de ser un tiempo libre. Y ello significa que profesores y alumnos ya no tienen tiempo para hacer lo que quieran, sino que tienen sus horas contadas, pues han de someter sus actividades a un programa. Sobre la disponibilidad de su tiempo se ha dictado sentencia de muerte: la muerte del tiempo libre. Y ello trae como consecuencia la pérdida de cierta idea de la gratuidad.

\subsection{Pasaje, camino, viaje}

El tercer aspecto que quería considerar es la naturaleza de ese pasaje, de ese «entre» en el que consiste la relación entre viejos y nuevos, entre adultos y jóvenes, entre las generaciones. Voy a referirme a dos interpretaciones posibles de ese «entre».

En primer lugar, el entre como espacio a colonizar. Una primera versión sería identificarlo con un camino hacia algo, o un ir hacia algún lugar que define una meta que ya se sabe dónde se encuentra y que concluye en algo, en algún otro lugar que creemos haber anticipado. Ese "entre» (entre el estado de infancia y el estado adulto; entre la inmadurez y la madurez; entre el no saber y el saber, etc.) sería aquí algo así como lo que se hace en un espacio y tiempo preparatorio que no tienen valor en sí mismos; sería lo que se hace entre un antes y un después, y 
como tal se trataría de una especie de "tierra de nadie», una tierra no colonizada pero que podría estar destinada a serlo. Una tierra que excita nuestros deseos de apropiación. Y, en segundo término, el entre como camino o como viaje. Podemos entender ese «entre», no como un espacio o un tiempo preparatorio para algo extrínseco, sino como un camino o un viaje. Es decir: como la realización de una experiencia. Se trata de un lugar de tránsito en el que pasan cosas; un lugar y un camino o una experiencia que valen por sí mismos.

Vamos a detenernos en esta segunda imagen. En esa experiencia, propiamente hablando, no habría un "método" que dijese anticipadamente cómo hay que caminar o viajar o experimentar (el aprender, por ejemplo); no es una trayectoria que se determine en función de unos objetivos previos, sino mediante el interés que la propia experiencia del camino va suscitando en el viajero, en el sujeto de la experiencia. Es un modo de hacer el camino, un modo de recorrerlo, una forma de colocar nuestros pasos, de caerse, tropezarse, avanzar, detenerse y seguir.

Hay un tipo de viaje que podemos concretar en la figura del "turista». "Tour-iste» comporta una carga semántica muy peculiar, y contiene dos elementos: por una parte, el sufijo «-ista", que indica la cualidad de lo excesivo o exasperante de una actitud, hábito o práctica; y, de otro lado, el significado de dicha actitud, hábito o práctica: "toun", "dar vueltas". Así, según esto, quien "da una vuelta» lo hace porque no tiene nada, o no tiene otra cosa, que hacer. Pero, al mismo tiempo, dar una vuelta es abrirse a todo lo que hay, es poder distraerse para, precisamente, poder captar, prestar atención, a más cosas. Es mirar de otro modo. Pero al turista el viaje se le ofrece como una experiencia ya hecha (ready-made), es decir, como ya construida, empaquetada, como si la experiencia directa y en bruto que alguien pudiera hacer no fuese del todo, o todavía, una experiencia significativa (González Marín, 2013, 11).

A este tipo de viaje podemos confrontar otra modalidad: el viaje no planificado, el viaje no organizado, el viaje que es una aventura que nadie más que el viajero construye. Si en el turista el viaje se ofrece como un prêt-à-vivre, en este otro viaje no es así: se trata de un viaje imprevisible, con el azar de sus paradas, la incertidumbre de las noches y la asimetría de todos los recorridos. Un viaje que siempre recomienza, que siempre hay que volver a empezar, cuando uno menos se lo espera, una especie de continuo preámbulo o un preludio de algo que está por venir y no se sabe qué es ni se puede anticipar. Viajar de este modo no es un simple medio para una meta o un fin, sino que es una experiencia valiosa en sí misma (realizarla es su propio fin), algo que concierne a la vida entera del sujeto de la experiencia, ya que cada decisión y cada elección que se toma sobre la marcha involucra toda la existencia. Viajar de este modo, como vamos a ver ahora, es un medio sin fin; y compromete un gesto.

\section{A MODO DE CONCLUSIÓN}

En su crítica de los apologistas del trabajo, Nietzsche hablaba, como hemos visto, de en qué medida la compulsión a la acción impersonal resta energías para 
la reflexión y la ocupación interesante de la vida. En esto podemos encontrar, es cierto, a un alemán que al oponer la Kultur a la Zivilization, como han sido dibujadas más atrás, enfatizaría una idea de la Bildung descomprometida políticamente. Estas contradicciones son reales, y hay que asumirlas como parte de un pensamiento, el nietzscheano, que alcanza su sentido en su no unidad. Muchas veces lanza conceptos y digresiones que no concluye, porque su propósito es provocarnos y darnos a pensar. Como dijimos, hay que tomárselo en serio, aunque no al pie de la letra. Pero su provocación nos nutre.

Creo que Stefan Zweig, en su hermoso texto sobre Nietzsche, captó lo esencial del drama y la genialidad del filósofo alemán al sugerir que hay que abandonar definitivamente las preguntas típicas de "un maestro de escuela»:

¿"Qué quería Nietzsche»?, ¿"qué quería decir Nietzsche»?, ¿"qué sistema filosófico profesaba Nietzsche»? Nietzsche nada quiere, sino que está en poder de una pasión inconmensurable hacia la verdad. Nada persigue; Nietzsche nunca piensa para, con su pensamiento, instruir al mundo o hacerlo mejor, ni para buscar una posición contra las normas y las reglas, lo cual trae como consecuencia que el temerario se vea rodeado del aislamiento más irremediable y de una guerra sin esperanza (Zweig, 1999, 279-280).

En ese libro inmenso que es Así habló Zaratustra, una obra que -como bellísimamente escribe Béatrice Commengé (2013, 21) - no nace de un razonamiento ni de un análisis, sino del color del cielo y de la claridad del aire; del insomnio vencido o de una migraña dominada; de los caminos y de los senderos; de una inmensa soledad y de la desesperación en una sombría alcoba; del frío que estremece los músculos y torna de color azul labios y manos, o del calor que hincha los pies; en ese libro en el que todo pasa por el cuerpo, porque es él el que marca la ruta, el camino, la dirección y el destino; en ese libro, digo, Nietzsche, el último profeta, lo proclama: "No me entienden, no soy la boca para esos oídos. ¿Habrá que destrozarles primero los oídos para que aprendan a oír por los ojos [...]. Tienen algo de lo que están orgullosos. ¿Cómo llaman a eso que tanto los enorgullece? Lo llaman formación, es lo que les distingue de los cabreros" (Nietzsche, 2015b, 72).

Hoy, esa vieja idea de la formación -que todavía usamos para referirnos a la educación- parece haber perdido la riqueza de su inmemorial pasado. Nuestros modos de encarar la educación de los jóvenes, lejos de ayudarles a madurar, los empequeñecen cada vez más y los alumnizan transformándoles en aprendices eternos. Al mismo tiempo, la llamada sociedad del aprendizaje les fuerza al diseño de su propia "formación" obligándoles a un cambio constante de actividad y de tarea. Incapaces de permanecer largo tiempo en una sola actividad, para iniciarse en la temporalidad natural del crecimiento personal y la propia maduración, devienen sujetos inscritos en la estulticia de la que hablaba Séneca en una de sus cartas morales a Lucilio. Insensatos, a su pesar, pero funcionales y actuales; ignorantes, aunque inocentes de su propia ignorancia. Este es el peor legado pedagógico que podemos ofrecerles. Un tremendo insulto a su condición de homo educandus. La 
consecuencia, entonces, es la producción de una incesante fatiga. Una fatiga que siempre se acumula -en una vida hiperactiva- y que denota una profunda pobreza de la experiencia; hacemos muchas cosas sin que nada nos pase en realidad: Do it!, Yes, we can!, cultura del proyecto y de la emprendeduría, tensión productivista (Perán, 2016, 31). Hay aquí toda una configuración del aprendiz que lo define como empresario de sí mismo permanentemente en curso, un modo de ser alumno que se construye bajo la exigencia de una constante autorresponsabilidad y flexibilidad -perfectamente moldeable y adaptable-, un sujeto emprendedor y constantemente adaptable a los cambios sucesivos del entorno (Jódar, 2007, 169).

El alumno "actualizado", pues, como sujeto emprendedor que se forma bajo la exigencia de hacer de su vida un negocio, una oportunidad para maximizar ganancias. El resultado es la introducción en el sistema educativo de la banalidad y del principio de superficialidad: un sistema educativo que arrastra a la gente al trabajo móvil y que favorece la facilidad a expensas de la profundidad. Nietzsche decía, en sus conferencias Sobre el porvenir de nuestras escuelas, que la causa de que no se manifieste por ningún lado una "completa honradez" es la "completa pobreza espiritual de nuestra época», y que precisamente en ese campo parecen ausentes los talentos verdaderamente inventivos, los individuos prácticos, que son, añadía, los que tienen buenas ideas y nuevas, y que no ignoran que la genialidad y la auténtica praxis se dan cita en el mismo sujeto. En cambio, la practicidad prosaica está repleta de falta de buenas ideas, de pensamiento, de reflexión. Y añadía algo que a algunos nos sobrecoge; decía: "Basta con entrar en contacto con la literatura pedagógica de nuestra época: hay que estar muy corrompido para no asustarse -cuando se estudia ese tema- ante la suprema pobreza espiritual, ante el desdichado juego infantil del coro" (Nietzsche, 2001, 60-61). Durísimas palabras, sin duda, que sirven de advertencia.

Ahora bien, esa profundidad de la que nos habla el filósofo nada tiene que ver con esencias ni con invisibilidades. Se trata de una profundidad que se cuenta con el cuerpo, con el individuo que siente, padece, siente y se angustia, con el que está atravesado de experiencias; tiene que ver con el individuo singular, con su cuerpo y con su piel -lo más profundo es la piel, decía Paul Valèry-, esto es, con las apariencias: con lo que se ve y con lo que se toca. Si hemos de ser superficiales, hagámoslo a la griega, pues "los griegos eran superficiales ipor su profundidad!" (Nietzsche, 2000, 59).

\section{REFERENCIAS BIBLIOGRÁFICAS}

Agamben, G. (2001) Desnudez. Barcelona, Anagrama.

Agamben, G. (2005) Lo abierto. El hombre y el animal. Valencia, Pre-Textos.

Agamben, G. (2015) ¿Qué es un dispositivo? Barcelona, Anagrama.

ANTElo, E. (2005) Notas sobre la (incalculable) experiencia de educar, en Frigerio, G. y Diker, G. (comps.) Educar: ese acto político. Buenos Aires, Del Estante Editorial, $173-183$. 
AREndT, H. (2005) La condición humana. Barcelona, Paidós.

Arendt, H. (2006) Between Past and Future. New York, Penguin Press.

ARISTÓTELEs (2011) Metafísica. Madrid, Gredos.

Astor, D. (2014) Nietzsche. Le détresse du présent. París, Gallimard.

BÁrCENA, F. (2016) En busca de una educación perdida. Rosario (Argentina), Homo Sapiens Ediciones.

BARTHES, R. (2003) Cómo vivir juntos. Situaciones novelescas de algunos espacios cotidianos. Notas de cursos y seminarios en el Collège de France, 1976-77. Buenos Aires, Siglo XXI Editores.

Chambers, J. (2010) La sociedad de aprendizaje [en línea]. Consultado el 16 de mayo de 2016. http://www.cisco.com/c/dam/en_us/about/citizenship/socio-economic/docs/ TLS_Spanish.pdf.

Derrida, J. (2010) La verdad en pintura. Buenos Aires, Paidós.

FINK, E. (1969) La filosofía de Nietzsche. Madrid, Alianza Editorial.

Foucault, M. (2005) Hermenéutica del sujeto. Curso del Collège de France (1982). Madrid, Akal.

Fuentes Megías, F. (2015) Una educación filosófica. Arte de vivir, experiencia y educación. Tesis doctoral. Universidad Complutense de Madrid.

GARY, R. (2010) Europa. Barcelona, Galaxia Gutenberg/Círculo de Lectores.

GONZÁlez MARín, C. (2013) Ciudadano ready-made. La formación humanística y la recuperación de la experiencia. Madrid, Díaz \& Pons.

GreISH, J. (2015) Vivre en philosophant. Espérience philosophique, exercises spirituels et thérapies de l'âme. París, De Visue.

HeIdegGer, M. (2005) ¿Qué significa pensar? Madrid, Trotta.

JóDAR, F. (2007) Alteraciones pedagógicas. Educación y políticas de la experiencia. Barcelona, Laertes.

KAFKA, F. (1953) Él. Anotaciones fragmentarias del año 1920, en La muralla china. Madrid, Alianza.

KoubA, P. (2009) El mundo según Nietzsche. Barcelona, Herder.

Lemm, V. (2009) La filosofía animal de Nietzsche. Cultura, política y animalidad del ser bumano. Chile, Ediciones Universidad Diego Portales.

Lemm, V. (2013) Nietzsche y el pensamiento politico contemporáneo. México, FCE.

LEPENIES, W. (2008) La seducción de la cultura en la historia alemana. Buenos Aires, Emecé editores.

Lorenzini, D. (2015) Ethique et politique de soi. Foucault, Hador, Cavell et les techniques de l'ordinaire. París, Librarie Philosophique J. Vrin.

Masschelein, J. (2001) The Discourse of the Learning Society and the Loss of Childhood. Journal of Philosophy of Education, 35: 1, 1-20.

Mondzain, M. J. (2007) Homo Spectator. París, Bayard.

Morice, J. (2016) Le Monde ou la Bibliohèque. Voyage et éducation à l'âge clasique. París, Les Belles Lettrres/essais.

Murdoch, I. (2016) El fuego y el sol. Por qué Platón desterró a los artistas. Madrid, Siruela.

Nehamas, A. (2005) El arte de vivir. Valencia, Pre-Textos.

NieTzSCHe, F. (2000) El gay saber o la gaya ciencia. Madrid, Espasa Calpe.

Nietzsche, F. (2001) Sobre el porvenir de nuestras escuelas. Barcelona, Tusquets.

Nietzsche, F. (2004) Fragmentos póstumos. Una selección. Madrid, Abada Editores.

Nietzsche, F. (2005) Nosotros, los filólogos. Madrid, Biblioteca Nueva. 
Nietzsche, F. (2006) La genealogía de la moral. Madrid, Alianza.

Nietzsche, F. (2007) Fragmentos póstumos. Madrid, Tecnos, vol. II.

NieTzsche, F. (2008) Friedrich Nietzsche Sämtliche Werke, 15 Bänden. München, Deutscher

Taschenbuch Verlag.

NieTzsche, F. (2009) Fragmentos póstumos. Madrid, Tecnos, vol. IV.

Nietzsche, F. (2011a) Obras completas. Volumen I: Escritos de juventud. Madrid, Tecnos.

Nietzsche, F. (2011b) Ecce Homo. Cómo se llega a ser lo que se es. Madrid, Alianza.

Nietzsche, F. (2013) Crepúsculo de los ídolos, o Cómo se filosofa a martillazos. Madrid, Alianza.

Nietzsche, F. (2015a) Humano, demasiado humano. Madrid, Edaf.

Nietzsche, F. (2015b) Así habló Zaratustra. Madrid, Valdemar.

PARDO, J. L. (2004) La regla del juego. Sobre las dificultades de aprender filosofía. Barcelona, Galaxia Gutenberg-Círculo de Lectores.

Pavie, X. (2012) Exercices Spirituels. Leçons de la philosophique antique. París, Les Belles Lettres.

Perán, M. (2016) Indisposición general. Ensayo sobre la fatiga. Hondarribia, Editorial Hiru. PIZARNiK, A. (2007) Diarios. Barcelona, Lumen.

Platón (2002) Teeteto, en Diálogos, V. Madrid, Gredos.

Platón (2003) República, en Diálogos, IV. Madrid, Gredos.

RANCIÈRE, J. (2008) La lengua de la emancipación, en JACOTOT, J. Lengua materna. La enseñanza universal. Buenos Aires, Editorial Cactus, 11-22.

RANCIÈRE, J. (2009) Et tan pis pour les gens fatigués. París, Éditions Amsterdam.

Revault D'Allonnes, M. (2005) L’homme compassionnel. París, Éditions du Seuil.

SAFrANSKI, R. (2001) Nietzsche. Biografía de su pensamiento. Barcelona, Tusquets.

SALA Rose, R. (2007) El misterioso caso alemán. Un intento de comprender Alemania a través de sus artes. Barcelona, Alba.

SÁnchez-MECA, D. (2015) Nietzsche. La experiencia dionisiaca del mundo. Madrid, Tecnos.

SÁNCHEZ-MeCA, D. (2016) Conceptos en imágenes. La expresión literaria de las ideas. Madrid, Avarigani Editores.

SÉNECA (2014) Epístolas morales a Lucilio, I. Madrid, Gredos.

SkLIAR, C. (2014) Desobedecer a linguagem. Educar. São Paulo, Autêntica.

STIGLTZ, J. y GREENWALD, B. (2016) La creación de una sociedad del aprendizaje. Una nueva aproximación al crecimiento, el desarrollo y el progreso social. Madrid, La Esfera de los Libros.

STIRNER, M. (2013) El único y su propiedad. Madrid, Valdemar.

ZWEIG, S. (1999) La lucha contra el demonio (Hölderlin, Kleist, Nietzsche). Barcelona, El Acantilado. 